\title{
APLIKASI METODE PCR YANG DIMODIFIKASI UNTUK KEPENTINGAN DIAGNOSA STREPTOCCOCIS
}

\author{
Hessy Novita, Lila Gardenia, Isti Koesharyani, Hambali Supriyadi, \\ dan Yani Aryati \\ Pusat Riset Perikanan Budidaya \\ Jl. Ragunan 20, Pasar Minggu, Jakarta Selatan 12540 \\ E-mail: hesta_biotek@yahoo.com
}

Naskah diterima: 3 Februari 2009; Diterima publikasi: 14 April 2009

\begin{abstract}
ABSTRAK
Bakteri merupakan salah satu penyebab penyakit pada ikan selain parasit dan virus. Walaupun tidak menimbulkan kematian massal namun keberadaan penyakit bakterial sangat merugikan kegiatan budidaya ikan. Tujuan penelitian ini adalah untuk memperoleh metode aplikasi yang mudah dan cepat untuk mendiagnosa penyakit bakterial khususnya yang disebabkan oleh infeksi Streptococcus iniae. Penelitian ini telah dilaksanakan melalui beberapa tahapan yaitu: (1) Karakterisasi biokimia S. iniae. (2) Uji PCR menggunakan primer universal 16S rRNA dan primer spesifik LOX-1 dan LOX-2 S. iniae. Hasil riset menunjukkan bahwa isolat dari Balai Riset Perikanan Budidaya Air Tawar (BRPBAT), Bogor dan isolat dari Laboratorium Riset Kesehatan Ikan (LRKI), Jakarta hasil uji PCR dengan 16S rRNA adalah positif sedangkan dengan primer LOX-1 dan LOX-2 hasilnya negatif untuk isolat $S$. iniae BRPBAT dan positif untuk isolat LRKI. Dengan uji PCR, diagnosa penyakit bakteri lebih cepat, spesifik, dan sensitif serta lebih akurat dibandingkan dengan karakterisasi secara biokimia yang membutuhkan waktu 2-3 hari untuk identifikasi.
\end{abstract}

KATA KUNCl: Streptococcus iniae, karakteristik, uji PCR, dan primer spesifik

ABSTRACT: The application of modified PCR method for streptoccocis diagnose. By: Hessy Novita, Lila Gardenia, Isti Koesharyani, Hambali Supriyadi, and Yani Aryati

Bacterial diseases has become an important diseases that have to be faced by aquaculturist. Even though unlike parasites, viral and bacterial diseases have caused fish farmers suffered great losses. The aim of the research was to develop a rapid detection method for bacterial disease especially for detecting Streptococcus iniae. The research was done in several steps which were (1) Biochemical characterization (2) PCR assay using universal primer for S. iniae 165 rRNA and specific primer LOX1 and LOX-2. The results showed that based on biochemical characterization, the isolate was belonged to S. iniae. PCR assay of isolate collected from the Research Institute for Freshwater Aquaculture (RIFA) Bogor and isolate from the Research Laboratory for Fish Health (RLFH) with $16 S$ rRNA were positive. However, RIFA isolate was negative and RLFH isolate was positive for S. iniae tested using LOX-1 and LOX2. The PCR assays offers more faster, specific, sensitive and accurate in identifying bacterial diseases compared to biochemical characterization that needs up to 3 days or more for bacterial identification.

KEYWORDS: Streptococcus iniae, characterization, PCR assay, and specific primer 


\section{PENDAHULUAN}

Penyakit ikan merupakan salah satu masalah yang timbul pada usaha budidaya ikan nila di Keramba Jaring Apung (KJA). Seperti telah sering dilaporkan pada budidaya intensif di KJA, telah terjadi kematian pada ikan ukuran diatas $200 \mathrm{~g}$ dengan gejala mata menonjol, dan kulit mengalami pendarahan.

Penyakit ikan, selain disebabkan oleh parasit dan virus, dapat juga disebabkan oleh bakteri. Penyakit bakterial merupakan salah satu masalah serius yang selalu dihadapi oleh petani ikan karena penyakit tersebut selain dapat mengakibatkan kematian sekitar 50\%100\% (Supriyadi \& Taufik, 1981; Supriyadi \& Rukyani, 1990), juga dapat menurunkan mutu daging dari ikan yang terinfeksi berupa borok atau luka, sehingga tidak disenangi oleh konsumen. Penelitian yang telah dilakukan pada tahun 1991/1992 telah membuktikan bahwa ikan nila dapat terinfeksi oleh bakteri Aeromonas hydrophila dan Enterobacter sp. (Supriyadi, 1992).

Hasil penelitian yang telah dilaksanakan pada tahun 2002 dan 2003 menunjukkan bahwa ikan nila sangat rentan terhadap infeksi penyakit bakterial terutama akibat infeksi bakteri S. iniae. Penyakit ini telah banyak mengakibatkan kerugian berupa kematian baik pada benih ikan nila maupun pada ikan nila ukuran konsumsi. Kematian yang diakibatkannya dapat mencapai lebih dari $75 \%$ dari populasi (Perera et al., 1994). Selain itu juga dilaporkan bahwa penyakit ini merupakan penyakit yang bersifat zoonotik (Holden, 1996, Weinsstein et al., 1997 dalam Bowser et al., 1998). Penyakit ini umumnya lebih banyak terjadi dan menimbulkan wabah pada ikan-ikan yang hidup di lingkungan yang kurang mendukung dan yang dalam keadaan stres.

Akibat budidaya yang terlalu intensif, saat ini infeksi bakteri Streptococcus menjadi problem utama dalam budidaya ikan di seluruh dunia, seperti di Jepang, Italia, Israel, Spanyol, Perancis, dan Amerika (Chen et al., 2001).

Saat ini deteksi cepat untuk bakteri penyebab penyakit belum banyak dikembangkan, sedangkan isolasi dan identifikasi bakteri masih kompleks dan memerlukan waktu cukup lama. Hal ini dirasakan perlu dikembangkannya metode yang dapat mendiagnosa bakteri
Steptococcus dengan cepat dan akurat, antara lain dengan Polimerase Chain Reaction (PCR).

\section{BAHAN DAN METODE}

\section{Karakterisasi Bakteri Streptococcus inniae}

Isolat bakteri dikumpulkan dari beberapa daerah yaitu Jawa Barat, Jawa Tengah, dan isolat bakteri koleksi dari Laboratorium Riset Kesehatan Ikan, Jakarta, serta isolat S. iniae yang merupakan koleksi Balai Riset Perikanan Budidaya Air Tawar, Bogor yang telah diuji biokimia. Isolat-isolat tersebut kemudian diuji karakterisasi kembali secara biokimia konvensional dan menggunakan kit (API strep2000). Karakterisasi meliputi pewarnaan gram, katalase, xylosa, galaktosa, sorbitol, manitol, sukrosa, arabinosa, dextrose, laktosa, inusitol, sorbitol sedangkan untuk gula-gula meliputi uji sakarosa, melabinosa, amylase, arabinose, dan uji haemolisis menggunakan blood agar base yang diperkaya dengan $2 \%$ darah domba.

Karakterisasi biokimia dilakukan di Balai Riset Perikanan Budidaya Air Tawar, Bogor dan di Laboratorium Riset Kesehatan Ikan-Pasar Minggu (untuk kit/API strep-2000). Isolat yang telah dimurnikan disimpan dalam media Brain Heart Infusion Agar (BHIA) dalam inkubator pada suhu $28^{\circ} \mathrm{C}$. Bakteri dipanen dari kultur $S$. iniae dalam media BHIA setelah berumur 24 jam dan kemudian disimpan dalam $3 \mathrm{~mL}$ alkohol 90\%. Selanjutnya kultur tersebut di-aliquot masing-masing sebanyak $100 \mu \mathrm{L}$ dalam 3 tube, kemudian suspensi bakteri tersebut siap untuk diekstraksi DNA-nya dengan 3 macam metode.

\section{Ekstraksi DNA Bakteri Streptococcus iniae}

DNA bakteri diekstraksi menggunakan 3 metode yaitu dengan pemanasan, kit fermentas dan isolasi dengan Kit DNAzol (Invitrogen Life Technologies, California, USA) (Mortada et al., 2006).

\section{Metode Pemanasan}

Isolat bakteri dimasukkan ke dalam mikrotube $1,5 \mathrm{~mL}$ yang berisi $200 \mu \mathrm{L}$ RNAse free water steril. Mikrotube dipanaskan pada suhu $95^{\circ} \mathrm{C}$ selama 10 menit pada alat thermomixer dan selama pemanasan tersebut mikrotube tersebut sekali-kali divortex untuk membantu menghancurkan dinding sel bakteri. Setelah dipanaskan, dilakukan pengendapan 
debris sel dengan cara disentrifuse pada 12.000 rpm selama 10 menit. Supernatan yang diperoleh dipindahkan ke mikrotube baru dan disimpan pada freezer (suhu- $20^{\circ} \mathrm{C}$ ) yang selanjutnya digunakan untuk uji PCR

\section{Metode Fermentas}

Isolat bakteri sebanyak $100 \mu \mathrm{L}$ kemudian ditambahkan $400 \mu \mathrm{L}$ lysis solution dan diinkubasikan pada suhu $65^{\circ} \mathrm{C}$ selama 5 menit. Kemudian ditambahkan $600 \mu \mathrm{L}$ chloroform dan dikocok dengan cara membolak-balikkan 3-5 kali dan sentrifugasi pada $10.000 \mathrm{rpm}$ selama 2 menit. Larutan presipitasi disiapkan dengan mencampurkan $720 \mu \mathrm{L}$ aquades steril (nuclease-free) dengan $80 \mu \mathrm{L}$ larutan $10 \mathrm{x}$ concentrated. Kemudian dipindahkan bagian yang bening yang mengandung DNA ke dalam larutan presipitasi, dicampurkan dengan membolak-balikkan selama 1-2 menit. Disentrifugasi pada $10.000 \mathrm{~g}$ selama 2 menit dan dibuang cairannya tetapi jangan sampai kering. DNA dilarutkan dengan $100 \mu \mathrm{L}$ 1,2 M $\mathrm{NaCl}$ kemudian divortex dengan kuat dengan memastikan bahwa DNA benar-benar larut. Selanjutnya ditambahkan $300 \mu \mathrm{L}$ ethanol absolut dingin, dan disimpan pada suhu $-20^{\circ} \mathrm{C}$ selama 10 menit serta di-spin-down dengan 1.000 g selama 3-4 menit. Kemudian ethanolnya dibuang dan DNA yang diperoleh dilarutkan dengan $100 \mu \mathrm{L}$ nuclease-free water.

\section{Metode DNAzol}

Isolat bakteri S. iniae sebanyak $100 \mu \mathrm{L}$ dalam mikrotube baru ditambahkan $500 \mu \mathrm{L}$ DNAzol, digerus dengan pestel. Kemudian disentrifugasi pada $12.000 \mathrm{rpm}$ selama 10 menit dan supernatan dipindahkan ke mikrotube baru untuk ditambahkan $500 \mu \mathrm{L}$ $100 \%$ ethanol, diinkubasi pada suhu ruang selama 1-3 menit, dan disentrifugasi pada 8.000 rpm selama 2-3 menit, kemudian cairannya dibuang. Pellet DNA ditambahkan $500 \mu \mathrm{L}$ 95\% ethanol dan dibolak-balik, selanjutnya dilakukan sentrifugasi pada 8.000 rpm selama 2-3 menit, cairannya dibuang, segera setelah 5-15 detik ditambahkan $50 \mu \mathrm{L}$ $\mathrm{NaOH} 8 \mathrm{~mm}$ dan 1,6 $\mu \mathrm{L}$ hepes.

\section{Amplifikasi DNA Bakteri Streptococcus iniae}

DNA S. inae yang telah diekstrak dilakukan uji PCR dengan menggunakan primer universal 16S ribosomal RNA (16S rRNA) untuk menentukan kromosom DNA S. Inae dengan primer pA/5'AgAgTTTgATCCTggCTCAg dan $\mathrm{pH} / 5^{\prime}$ 'AaggAgg TgATCCAgCCgCA dengan suhu denaturasi $92^{\circ} \mathrm{C}$ selama 2 menit, annealing $55^{\circ} \mathrm{C}$ selama 1 menit, extension $72^{\circ} \mathrm{C}$ selama 1,5 menit sebanyak 25 kali, final extension $72^{\circ} \mathrm{C}$ selama 5 menit (Perera et al., 1994). DNA diamplifikasi menggunakan spesifik primer LOX-1: AAg ggg AAA TCg CAA gTg CC dan LOX2: ATA TCT gAT Tgg gCC gTC TAA (Mata et al., 2004) dan dibandingkan dengan positif kontrol, dengan target berat molekul $870 \mathrm{bp}$. Positif kontrol yang digunakan dalam uji PCR berasal dari bakteri S. iniae yang disimpan dalam alkohol 95\% dan lisis buffer, yang diperoleh dari Oonoonba Veterinary Laboratory Townsville, Australia.

Amplifikasi menggunakan master mix merk fermentas. Kemudian proses amplifikasi menggunakan mesin Thermal cycler dengan suhu pre-denaturasi $94^{\circ} \mathrm{C}$ selama 2 menit, denaturasi pada suhu $92^{\circ} \mathrm{C}$ selama 60 detik, annealing pada suhu $52^{\circ} \mathrm{C}-55^{\circ} \mathrm{C}$ selama 60 detik dan extension pada suhu $72^{\circ} \mathrm{C}$ selama 90 detik sebanyak 25 kali. Final Extension pada suhu $72^{\circ} \mathrm{C}$ selama 5 menit, suhu penyimpanan pada $4^{\circ} \mathrm{C}$ sampai akan dielektroforesis (Mata et al., 2004; Mortada et al., 2006).

\section{Visualisasi dan Dokumentasi Hasil}

Hasil amplifikasi dielektroforesis pada $2 \%$ agarose menggunakan 1 × TAE (Tris Acetate EDTA) Buffer. Marker yang digunakan sebagai pembanding adalah 100 bp merk Fermentas. Hasil elektroforesis diwarnai dengan Ethidium Bromida selama 15 menit dan dibaca pada $V$ Transilluminator kemudian didokumentasikan menggunakan foto polaroid.

\section{HASIL DAN BAHASAN}

\section{Karakterisasi Bakteri Streptococcus iniae}

Hasil isolat bakteri dari ikan nila yang berasal dari Waduk Cirata dan Jawa Tengah ketika dikultur kembali ternyata tidak tumbuh pada media BHIA, sehingga proses $u j \mathrm{j}$ karakterisasinya tidak dapat dilanjutkan. Sedangkan hasil karakterisasi isolat S. iniae yang merupakan koleksi Balai Riset Perikanan Budidaya Air Tawar, Bogor hasilnya positif dan isolat bakteri dari Laboratorium Riset Kesehatan Ikan (LRKI) Jakarta menunjukkan bahwa isolat tersebut kecenderungan kearah bakteri $S$. iniae yang bisa dilihat pada uji biokimia pada Tabel 1 dan Gambar 1 . 
Tabel 1. Hasil uji biokimia konvensional Streptococcus iniae Table 1. Biochemical test for Streptococcus iniae

\begin{tabular}{lc}
\hline $\begin{array}{c}\text { Asal sampel ikan nila } \\
\text { Sample location of tilapia }\end{array}$ & $\begin{array}{c}\text { Hasil uji biokimia } \\
\text { Biochemichal test }\end{array}$ \\
\hline Jawa Barat (Waduk Cirata) & Negatif \\
Jawa Tengah & Negatif \\
Koleksi BRPBAT-Bogor & Positif \\
Koleksi LRKI-Jakarta & Positif \\
\hline
\end{tabular}

\section{Ekstraksi DNA Bakteri Streptococcus iniae}

Proses ekstraksi DNA bakteri S. iniae dilakukan dengan menggunakan 3 metode, yaitu dengan cara pemanasan, Fermentas, dan DNAzol. Dari 3 metode yang diujikan tersebut, metode pemanasan merupakan teknik yang paling sederhana, murah, cepat, dan mudah dalam penggunaannya serta ekstrak DNA yang dihasilkan lebih bersih yang divisualisasikan dalam hasil elektroforesis jika dibandingkan dengan metode ekstraksi dengan Fermentas dan DNAzol (Gambar 2).

\section{Uji PCR}

Hasil uji PCR dari sampel isolat bakteri $S$. iniae Laboratorium Riset Kesehatan Ikan dan $S$. iniae yang merupakan koleksi Balai Riset
Perikanan Budidaya Air Tawar, Bogor dengan 16S rRNA hasilnya positif dengan berat molekul 1.500 bp yang menandakan bahwa isolat bakteri adalah bakteri $S$. iniae dan menunjukkan homologi kedua sampel dengan positif kontrol yang dapat dilihat pada Gambar 3. Sedangkan hasil uji PCR untuk menentukan spesifik $S$. iniae pada ikan nila yang menggunakan primer spesifik $S$. iniae dengan primer foward LOX-1 dan primer reverse LOX-2 dengan berat molekul 870 bp hasilnya positif untuk isolat dari Laboratorium Riset Kesehatan Ikan, sedangkan isolat koleksi Balai Riset Perikanan Budidaya Air Tawar Bogor hasilnya negatif (Gambar 4). Berbedanya hasil uji identifikasi PCR antara 16S rRNA dengan primer spesifik $S$. iniae antara kedua isolat kemungkinan $S$. iniae dari isolat BRPBAT dengan isolat LRKI adalah berbeda spesies

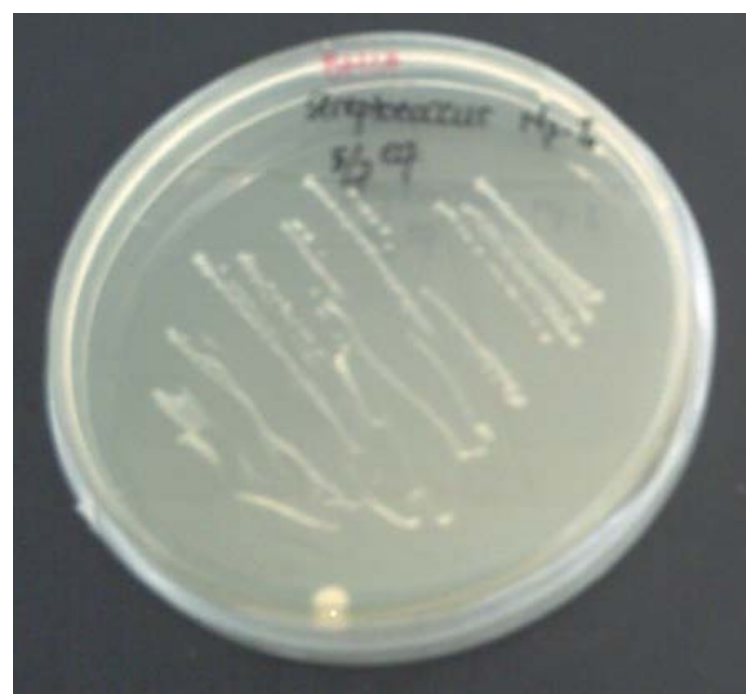

Gambar 1. Isolat bakteri Streptococcus iniae

Figure 1. Streptococcus iniae isolate 


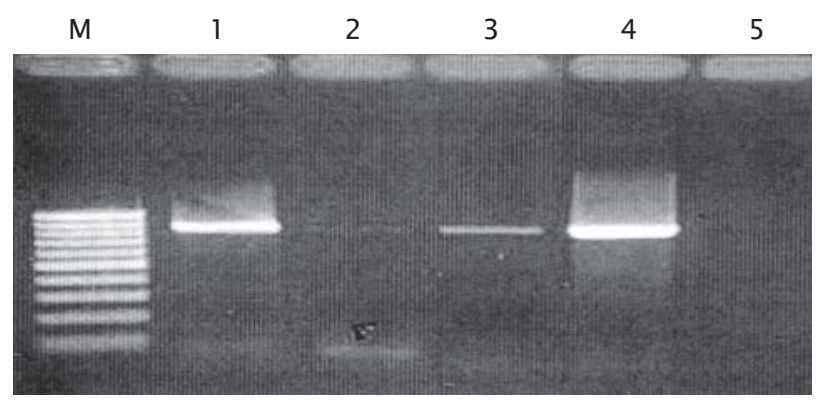

Gambar 2. Hasil ekstraksi DNA S. iniae dengan 3 macam metode. M. Marker; Lane 1. Metode pemanasan; Lane 2. Metode DNAzol; Lane 3. Metode Fermentas; Lane 4. kontrol positif; Lane 5 . kontrol negatif

Figure 2. DNA Extractions of S. Iniae with 3 methods: M. Marker; Lane 1. Boiling Method; Lane 2. DNAzol Method; Lane 3. Fermentas Method; Lane 4. positive control; Lane 5. negative control

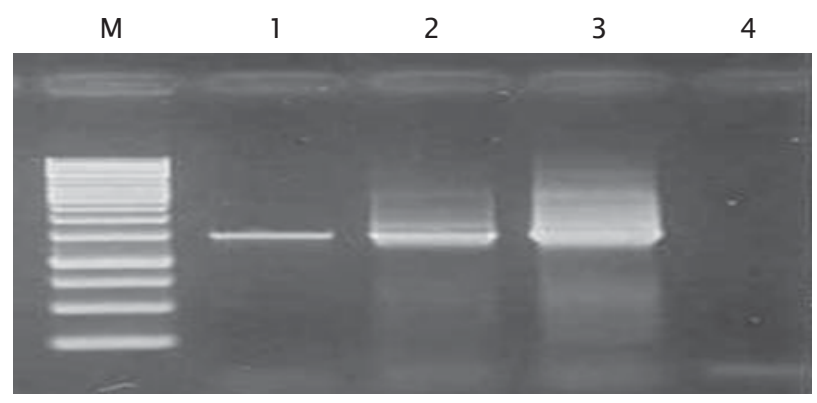

Gambar 3. Hasil uji PCR dengan 16S rRNA. M. Marker 1 Kb; Lane 1 Isolat Streptococcus iniae dari BRPBAT Bogor; Lane 2 Isolat S. iniae dari LRKI Jakarta; Lane 3 Kontrol Positif; Lane 4 Kontrol Negatif

Figure 3. 16 SrRNA Test by PCR. M. Marker $1 \mathrm{~Kb}$; Lane 1. Isolate S. iniae from RIFA, Bogor; Lane 2 S. iniae isolate RFLH, Jakarta; Lane 3 Positive control; Lane 4 Negative Control

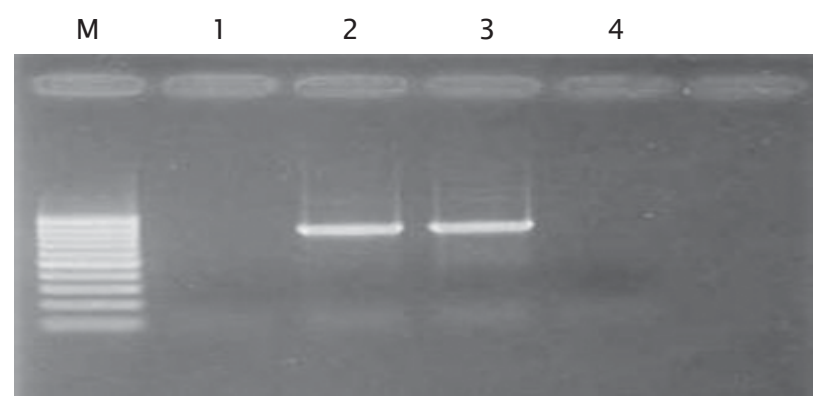

Gambar 4. Hasil uji PCR dengan spesifik primer Streptococcus iniae dengan primer LOX-1 dan LOX-2. M. Marker 100 bp; Lane 1 S. iniae isolat dari BRPBAT Bogor; Lane 2 S. iniae isolat dari LRKI Jakarta 1 ; Lane 3 Kontrol Positif; Lane 4 Kontrol Negatif

Figure 4. PCR test with spesific primer for S. iniae by LOX-1 and LOX-2. M. Marker 100 bp; Lane1 S. iniae isolate from RIFA, Bogor; Lane 2 S. iniae isolate from RFLH, Jakarta; Lane 3 Positive control; Lane 4 Negative Control 
yang berarti bahwa primer LOX-1/LOX-2 tidak spesifik untuk amplifikasi isolat dari BRPBATBogor.

Teknik PCR sebagai alat diagnosa secara molekuler dapat meningkatkan secara signifikan dalam mendeteksi dan mengidentifikasi beberapa bakteri secara klinis baik pada hewan maupun pada manusia. Uji PCR dengan 16S rRNA untuk menentukan target molekul (Zlotkin et al.,1998; Gibello et al., 1999; Blanco et al., 2002) sebagai gambaran untuk identifikasi antar genus dan semua strain S. iniae pada tingkat gen $16 \mathrm{~S}$ rRNA. Sedangkan amplifikasi DNA dengan primer LOX-1 dan primer LOX-2 lebih spesifik dari 16S rRNA pada uji PCR (Zlotkin et al., 1998). Hal ini menunjukkan primer LOX-1/LOX-2 yang mengkode gen Lactate-oxidase (IctO) memberikan amplifikasi tunggal dengan target molekul 870 bp ini hanya spesifik ada pada $S$. iniae dengan homologus pada beberapa bakteri seperti $A$. viridans, S. equisup sp. zooepidemicus, S. Pyogenes, dan C. piscicola (Mata et al., 2004).

Dari hasil riset menunjukkan bahwa dengan uji PCR untuk identifikasi S. iniae merupakan metode yang lebih efektif, spesifik, sensitif, cepat, serta lebih akurat jika dibandingkan dengan metode konvensional secara biokimia. Dengan metode biokimia kurang sensitif dalam mengidentifikasi antar genus bakteri, karena ada beberapa uji biokimia hasilnya yang hampir sama antara satu spesies bakteri dengan bakteri yang lain sehingga menimbulkan kesalahan dalam penafsiran hasil, serta membutuhkan waktu 2-3 hari untuk identifikasi biokimia konvensional.

\section{KESIMPULAN DAN SARAN}

Primer Lox-1 dan primer LOX-2 lebih spesifik dari 16S rRNA untuk identifikasi $S$. iniae dengan tartget molekul $870 \mathrm{bp}$. Pengembangan teknik diagnosa secara molekuler dengan PCR dalam deteksi dan identifiasi bakteri, karena lebih cepat, sensitif, mudah, dan lebih akurat jika dibandingkan dengan uji biokimia konvensional. Untuk uji PCR selanjutnya adalah dengan mengisolasi S. iniae dari jaringan ikan nila yang terinfeksi bakteri ini dan aplikasi uji patogenitas untuk mengetahui dosis infeksi $S$. iniae terhadap ikan nila (Oreochromis niloticus).

\section{UCAPAN TERIMA KASIH}

Ucapan terima kasih ditujukan kepada Laboratorium Patologi Ikan, Balai Riset
Perikanan Budidaya Air Tawar, Bogor yang telah membantu dalam analisis biokimia pada pelaksanaan penelitian dan penelitian dapat terlaksana didukung oleh dana APBN serta Oonoonba Veterinary Laboratory Townsville, Australia yang juga memberikan isolat bakteri S. iniae sebagai kontrol positif PCR.

\section{DAFTAR ACUAN}

Blanco, M.M., Gibello, A., Vela, A.I., Moreno, M.A., Dominguez., L., \& Fernandez-Garaycabal, J.F. 2002. Winter disease outbreak in sea bream (Sparus aurata) associated with Pseudomonas anguilliseptica infection Dis. Aquat. Org., 50: 19-27.

Bowser, P.R., Wooster, G.A., Getchell, R.G., \& Timmons, M.B., 1998. Streptococcus innae Infection of Tilapia Oreochromis niloticus in a recirculation production Facility. Journal of The word Aquaculture, 29(3): 335-339.

Chen, S.C., Lin, U.D., Liaw, L.L., \& Wang, P.C. 2001. Lactococcus garvieae infection in the giant freshwater prawn Macrobranchium rosenbergii confirmed by polymerase chain reaction and $165 \mathrm{~S}$ DNA sequencing. Diseases of Aquatic Organisms, 45: 45-52.

Gibello, A., Collins, M.D., Dominguez, L., Fernandez-Garayzabal, J.F., \& Richardson, P.T. 1999. Cloning and analysis of the LLactate utilization genes from Streptococcus iniae. Appl. Environ. Microbiol., 65: 4,346-3,825.

Mata, A.I., Blanco, M.M., Dominggues, L., Fernandez-Garayzabal, J.F., \& Gibello, A. 2004a. Development of a PCR assay for Streptococcus iniae based on the Lactate oxidase (IctO) gene with potential diagnostic value. Veterinary Microbilogy, 101: 109116.

Mata, A.I., Gibello, A., Casamayor, A., Blanco, M.M., Dominguez, L., \& Fernandezgarayzabal, J.F. 2004b. Multiplex PCR assay for detection of bacterial pathogens associated with warm-water streptococcosis in fish. Applied and Environmental Microbiology, 70(5): 3,183-3,187.

Mortada, M., Hussein, A., \& Hatai, K. 2006. Multiplex PCR for detection of Lactococcus garvieae, Streptococcus iniae and $S$. dysgalactiae in cultured yellowtail Japanese Society for Aquaculture Research. Aquaculture Science, 54(3): 269-274.

Perera, R.P., Johnson, S.K., Collins, M.D., \& Lewis, D.H. 1994. Streptococcus iniae Associated with Mortality of Tilapia nilotica $\times$ T. aurea 
Hybrids. J. Aquatic Animal Health, 6: 335340.

Supriyadi, H. \& Taufik, P. 1981. Identifikasi dan cara penanggulangan penyakit bakterial pada ikan lele (Clarias batrachus). Bull. Perik., I(3): 447-454.

Supriyadi, H. \& Rukyani, A. 1990. Immunopropilaksis dengan cara vaksinasi pada usaha budidaya ikan. Seminar Nasional Ke II, Penyakit Ikan dan Udang, Bogor. 16-18 Januari 1990, hlm. 64-69.

Supriyadi, H. 1992. Identifikasi dan Cara Penanggulangan Pernyakit Bakterial
Pada Ikan Nila. Dalam Pros. Seminar Hasil Pen. Perik. Air Tawar 1991/1992 Cipayung 20-22 Oktober 1992. Hambali Supriyadi et al. (Eds.). Balai Penelitian Perikanan Air Tawar. Bogor. Pusat Penelitian dan Pengembangan Perikanan. Badan Penelitian dan Pengembangan Pertanian, hlm. 59-63.

Zlotkin, A., Hershko, H., \& Eldar, A. 1998. Possible transmission of Streptococcus iniae from wild fish to cultured marine fish. Appl. Environ. Microbiol., 64: 4,065-4,067. 